\title{
The effect of advertising on the market value of firms: Empirical evidence from the Super Bowl ads
}

Received (in revised form): 28th May, 2003

\section{Jooyoung Kim}

is an assistant professor of advertising in the Greenlee School of Journalism and Communication at lowa State University. He earned his $\mathrm{PhD}$ from the University of Florida. His research areas are in brand loyalty, brand extension and consumer affect.

\section{Jon D. Morris}

Professor in the Department of Advertising, College of Journalism and Communications, University of Florida, began his advertising career in 1968, and worked for several agencies before earning his PhD from the University of Florida. His research has appeared in Journal of Advertising Research, Journal of Current Issues in Advertising Research, Journal of Educational Technology and International Journal of Instructional Media, among others. He has recently been developing a model (AdSAM) for analysing emotional response to marketing communications. The model has been used in hundreds of proprietary studies for multinational companies worldwide.

\begin{abstract}
As integrated marketing communications increasingly emerge as the focus of corporate communication efforts, companies have grown to realise that consumers are not their only target audience. Rather, there are many stakeholder groups that also need to be targeted with the company messages. This research examines some of the important stakeholders - investors - and their perception of a company's advertising as reflected in the stock price performance at certain peak advertising periods. Using standard event-study methods with the sample focusing on selected companies and their Super Bowl ads, this study found a significantly different stock price performance (compared to that of the prior periods) for the companies that advertised.
\end{abstract}

Dr Jooyoung Kim Greenlea School of Journalism and Communications, Hamilton Hall, lowa State University, Ames, IA 50011, USA.

Tel: +1 515292 4986; Fax: +1515 294 5108; e-mail:

jykim@brandresearch.org

\section{Background}

News-based investment strategy is a well-known equity market principle. It functions under the empirical assumption that stock prices respond very quickly to new information. In general, some classes of news that can have an immediate effect on stock prices are, for example: earnings; analyst reports/ recommendations; contracts/alliances; and reorganisations. ${ }^{1}$ This principle prompts an interesting question: are advertisements (especially featuring new product/brand/company information aired in a very high-rating programme such as the Super Bowl) newsworthy for investors? Because effective advertisements can often initiate sales for a new brand or build positive images of a new or existing company, advertisements for investors can be perceived as a good indicator of positive future performance of the advertised company. Although there have been many research efforts studying whether advertising expenditure can be regarded as a financial investment, there have been very few research efforts studying the advertising's newsworthiness for consideration of investment in the advertised company. Do investors perceive advertising as a clue to a 
company's increase in performance? Will they react either positively or negatively to the advertising? This research empirically explores and examines these questions. The study will examine investors' perceptions, as measured by stock prices, regarding companies' promotional activities.

\section{ECONOMIC AND FINANCIAL VIEW OF ADVERTISING AS INVESTMENT}

Heavy television advertising in high-rated programmes is an important corporate event, due to the large dollar amounts typically involved as well as the expected impact on sales and the level of awareness in the market. Because of the mostly positive impact on a company's future earnings, it has been argued that advertising expenses are a form of investment, not just a single-period expense. $^{2-8}$ Many economists have also supported the view that advertising has a positive effect on companies and markets. ${ }^{9-11}$ Different or opposite views of advertising have also been offered, such as variations in the advertising/sales ratio, ${ }^{12-15}$ and advertising as an expense, ie that advertising costs incurred are deducted as a business expense in that year, since the economic benefits cannot be measured reliably for most types of advertising. ${ }^{16,17}$ The American Institute of Certified Public Accountants' Accounting Standards Executive Committee also views advertising as an expense, ${ }^{18}$ but this view in fact seems only to regard the matter of whether to put advertising in the 'expense' or 'investment' column on the balance sheets, and does not address the matter of conceptually viewing advertising as an expense or an investment.

In a strategic sense, however, advertising has often been viewed as a sales trigger, and thus, at least conceptually, as a form of investment. A causal link between advertising and sales (or a sales base) has been suggested by several studies. ${ }^{19,20}$ Broadbent $^{21}$ states that 'in an ideal world, if we invest an extra dollar in advertising, we would be able to identify, say, three dollars of extra sales caused by this advertising'. Other studies suggest that advertising campaigns have a significant intertemporal effect on sales by influencing consumption habits ${ }^{22-24}$ and in changing attitudes. ${ }^{25}$ Furthermore, some scholars find that advertising campaigns have positive effects on the market values of companies by providing information to equity investors on the expectations of cash flows. ${ }^{26,27}$ This suggests that investors may watch ads in much the same way as consumers who would have positive impressions from the ads and have positive purchase intentions of the advertised brands. Given the presence of the positive relationship between advertising and brand value,$^{28}$ it should be possible to reason that most investors would infer that advertising (in particular that which features new brand or company information) will bring about the heightened market value of the company through increased sales volume, or brand/company awareness due to the advertising. ${ }^{29-30}$ The conceptual procedure for this view follows the traditional $\mathrm{Aad} \rightarrow \mathrm{Ab} \rightarrow$ PI process (where Aad stands for attitude towards the ad, Ab attitude towards the brand and PI means purchase intention), that is, when investors watch an ad, they view the ad as if they were consumers. If this expectation is true, then it can be expected that reactions to the ad and the product being advertised will be similar to those of a consumer, ie a positive attitude towards the advertising leads to a positive attitude about the product and the product's company and positive expectations for future sales performances of a brand. If they have a positive Aad, 


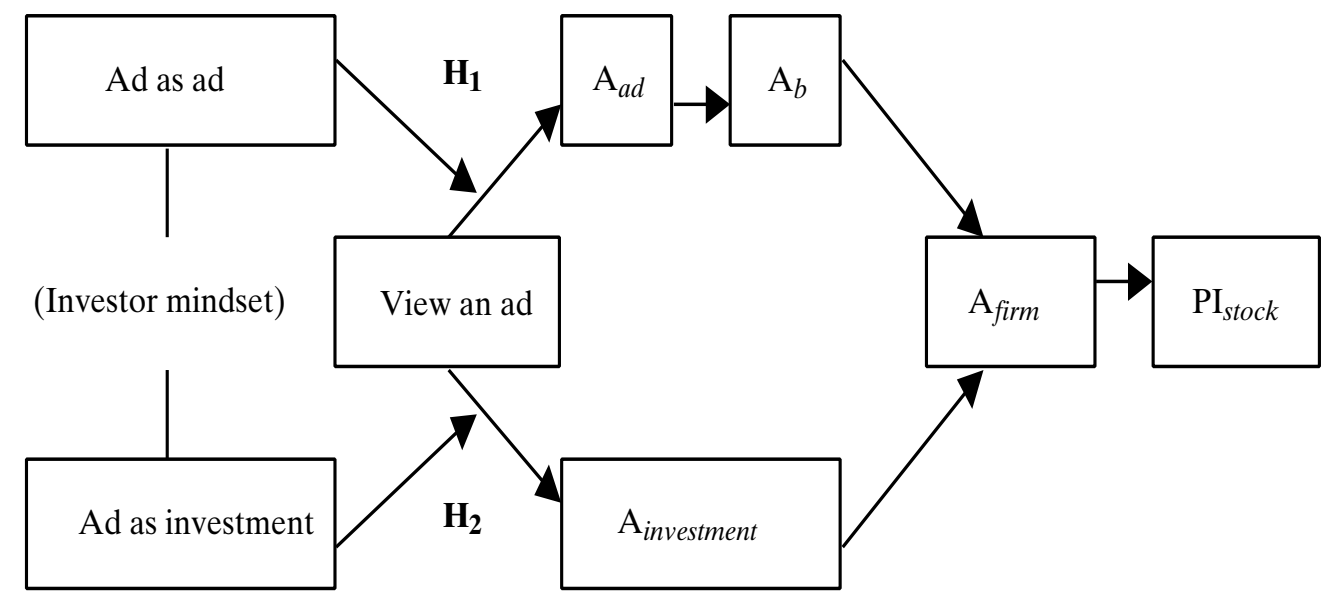

Figure 1 Conceptual model of ad-induced investment decision process

$\mathrm{Ab}$ and PI experience, then the market value of the stock of the company engaged in the advertising would be expected to increase, due to the positive performance of product as projected through the advertising. This leads to the first hypothesis:

$\mathrm{H}_{1}$ : Investors behave like consumers, and make investment decisions based on their response to ads as consumers.

Contrasting views also exist, however. Barth et al. ${ }^{31}$ have found that the relationship between advertising expense, brand value and the market value of company equity was seen to show a statistical interaction. They determined that while a positive relationship between advertising expense and brand value has been found, advertising expense surprisingly has a significantly negative relationship to the value of company equity (after controlling for brand value estimates and the other potential brand proxies). Another study shows that intangible assets such as goodwill, rights (patents, trademarks, etc), brands and advertising exhibit no significant positive relationship to stock price. Ely and Waymire $^{32}$ conclude that investors value companies primarily based on earnings, perhaps because they attach economic value to intangibles only when it is reflected in higher earnings rather than when investments are made. These research results imply that no investors would assess the value of the company based on intangibles such as advertisements. Therefore, the second hypothesis is:

\section{$\mathrm{H}_{2}$ : Investors view advertising as an investment, and therefore use a restricted approach to evaluating the impact of advertising on the market value of the advertised product's company.}

This conceptual model of hypotheses 1 and 2 is illustrated in Figure 1.

\section{THE PRESENT RESEARCH}

The current study was designed to determine if investors perceive advertising as a clue to potential positive (or negative) future earnings and, therefore, the company's value, or if they simply view ads as would any prospective customer of the product. That is, do they use the information when making a decision about a company's stock? Finding the 
answer to this question would most certainly help marketing communication researchers and practioners in their conception and implementation of marketing plans, and help them build profitable relationships with company stakeholders, the investors. ${ }^{33}$

With this in mind, this study examined investors' perceptions of advertising by investigating the advertised companies' stock price activities around the time when certain advertising took place, under the assumption that the stock price activities reflect the investor behaviours. Furthermore, any significant over- or under-performance of stock prices was investigated to determine differences in stock price performance by company types (eg dot.com, bricks-and-mortar, etc). This study used the 'event-study method' to investigate the stock price reactions to Super Bowl advertising. This method has been used extensively in finance literature and is widely perceived as an accurate indicator of stock market behaviour. ${ }^{34}$ A detailed review of this method is discussed later.

\section{SAMPLE: SUPER BOWL ADS OF 1998, 1999 and 2000}

Because of their potential for influencing investors, the sample chosen for this study was the past three years of Super Bowl advertisements. Some of the potential influences included the intensive time-frame to air the commercials (one four-hour event) as well as the likelihood of the significant impact implied via the high ratings for the programme, the newsworthy content and the presence of controversial debates about the efficiency as well as the effectiveness of Super Bowl ads. Super Bowl advertising has consistently been one of the biggest yearly events for the advertising industry, not only because of the large amount of money that is charged for the spots, but also for the newsworthiness of the content found in the ads, such as launching a new business (eg Victoria's Secret website in 1999), a new company (eg Computer.com in 2000), or just attractive and creative executions. For these reasons, several media companies such as CBS and USA Today have promoted the Super Bowl's Greatest Commercials (or Ad-Meter) after the games.

Although the most acknowledged perception has been that these spots attract the consumers' notice and bring a good deal of prominence and attention to a corporation in spite of the expense, ${ }^{35}$ there have been extensive debates about whether airing a commercial during the Super Bowl $(\$ 2.1 \mathrm{~m}$ per 30 seconds as of year 2001) makes marketing sense. Many marketers who support Super Bowl advertising argue that these spots bring them a large, captive audience (ratings over 40, see Table 1), significant post-Super Bowl publicity, and a word-of-mouth after-effect. Others argue that the commercial message needs to be part of an integrated marketing communication effort, or the large expenditure is simply wasted. ${ }^{36}$

This study gathered three years of applicable Super Bowl ads: 35 companies (that had gone public before the ads) that aired a total of 70 ads. As an example, Pets.com advertised during the Super Bowl in 1999, but was excluded from the sample because it was not a publicly traded stock at the time. The sampling time period was limited to three years in order to compare the stock performances of dot.com companies and traditional companies, as the dot.com ads are recent phenomena. The final sample brands and companies are shown in Table 2 .

This study also used USA Today's Ad-Meter scores for Super Bowl ads for the purpose of exploring the relationship between stock price performance and 
Table 1: Three years of Super Bowl ads

\begin{tabular}{lllll}
\hline Year & Price & Adj. Price & & \\
\hline 1998 & $\$ 1,300,000$ & $\$ 1,374,172$ & Rating $^{\star * *}$ & Viewers $^{\star * * *}$ \\
1999 & $\$ 1,600,000$ & $\$ 1,654,742$ & 44.5 & $90,000,000$ \\
2000 & $\$ 2,100,000$ & $\$ 2,100,000$ & 40.2 & $83,720,000$ \\
\hline
\end{tabular}

*Average price for 30 second commercial

${ }^{\star *}$ Adjusted for inflation to 2000 dollars

${ }^{\star \star \star}$ Percentage of US households

${ }^{* \star * \star}$ Age $2+$

Source: Advertising Age

consumers' attitudes towards the ads.

This analysis addresses the first hypothesis that questions whether investors view ads from the perspective of consumers. For example, a result that shows both significantly positive stock price increases and high Ad-Meter scores would tend to support the notion that there is a positive relationship between a company's stock price and a good attitude towards the advertising of the company's product $\left(\mathrm{H}_{1}\right)$. USA Today started the Super Bowl 'Ad-Meter' in 1989 to gauge consumers' opinions about Super Bowl ads. During each Super Bowl, volunteers (usually 100-250) chosen by a national polling organisation, using hand-held meters, register how much they like or dislike each ad shown during the game. The newspaper posted the results of the Ad-Meter on the Monday following the game. Although the Ad-Meter cannot be viewed as a measure with strong validity or external reliability mainly due to the sampling process (ie using volunteers), this study used the Ad-Meter scores and examined their relationship to the stock price performances, assuming the scores operationally represented consumer attitudes toward the ads at the time of the actual advertising.

\section{METHODS}

In order to investigate the hypotheses, first, it is necessary to determine if there were significant influences of ads on the market value of the company that is advertising. Hypothesis 1 was tested by investigating the relationships between Ad-Meter scores and stock price performances, and Hypothesis 2 was tested by using a newly created concept, the Financial Impact Size of Advertising (FISA) on the company that is advertising. Conceptually, FISA can be expressed as follows: Ad expense/ Company size. Thus the more a company spends on advertising compared to the company size, the higher the financial impact on the company. This conceptual aspect of FISA was used for the analysis of $\mathrm{H}_{2}$. If a high FISA leads to a significantly negative stock price performance (or vice versa), $\mathrm{H}_{2}$ is assumed to be supported.

This study used the event-study method to analyse the effects of advertising on the advertised company's stock price. This method provides an estimate of the unexpected change in share price around the advertising day. By design, an event study controls for all the relevant organisational or external factors (eg industry, profits, sales, assets, performance, equity) that may mediate or moderate the effect of advertising on the stock prices of companies. The event-study technique is an extensively used method in the finance literature, and is widely perceived as an accurate indicator of stock market behaviour. ${ }^{37}$ 
Table 2: Samples

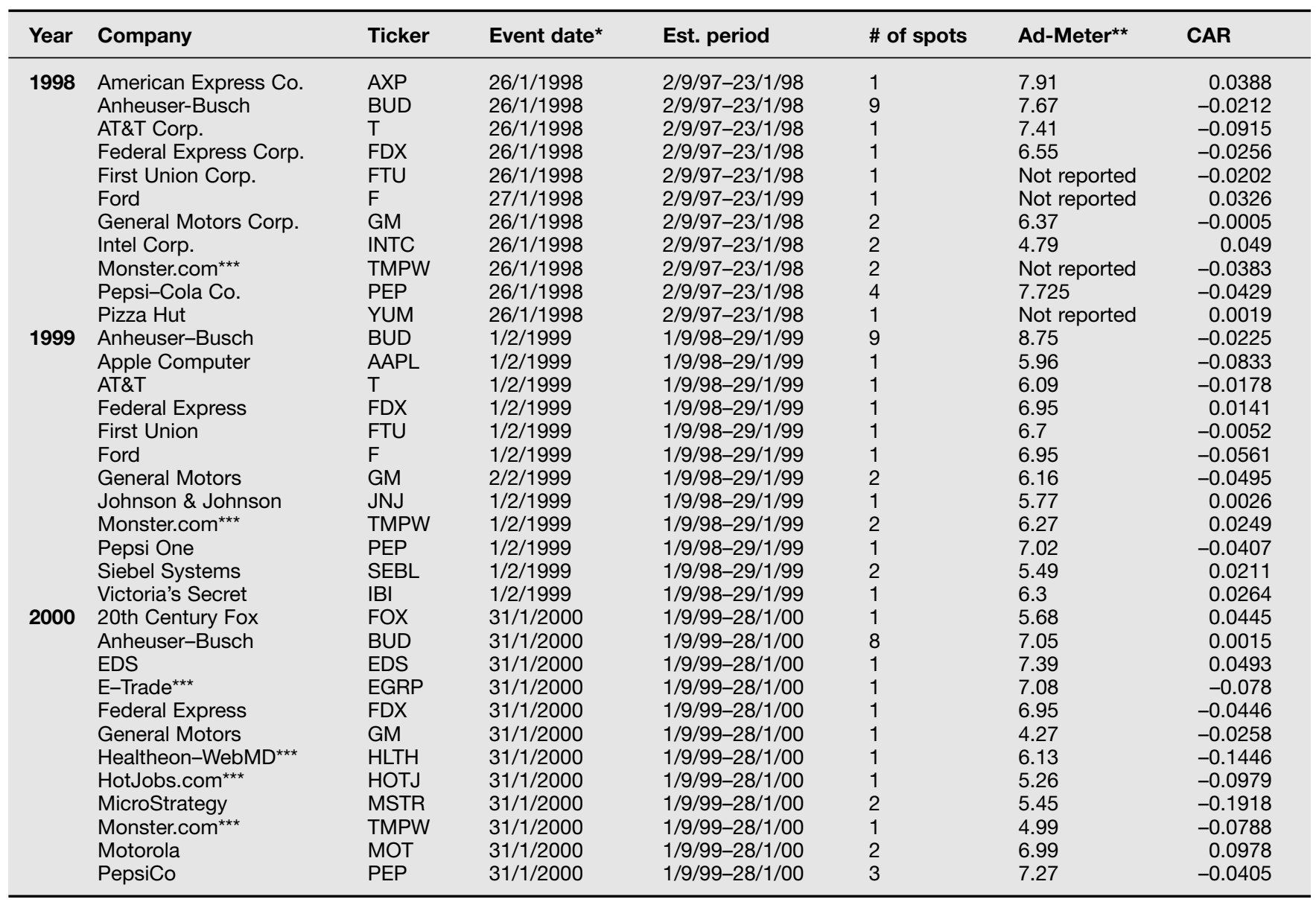

* Event date is the Monday after the Super Bowl Sunday because the stock market does not open on Sunday

** Source of Ad-Meter scores is USA Today. Scores for multiple ads are the average scores

*** Dot.com companies

The technique has been used in analysing several aspects of corporate incidents or behaviours on stock prices of the companies. For example, these events or incidents include the impact of the 1982 Tylenol poisoning incident; ${ }^{38}$ bank failures; ${ }^{39}$ unfavourable product information on television; ${ }^{40}$ various corporate financial incidents; ${ }^{41-44}$ the use of celebrity endorsers; ${ }^{45}$ and the brand extension announcements. ${ }^{46}$ Commonly, event studies follow four basic steps: ${ }^{47-50}$

- identifying an event to be studied

- modelling the expected shareholder returns
— estimating the unexpected shareholder returns

— analysing the unexpected returns.

The event studied was Super Bowl advertising. The expected shareholder returns were predicted using the past returns during the 'estimation period', a control period of time before the date of the Super Bowl. Thus, the estimation period reflected a period not influenced by the event in question (ie Super Bowl ads). Regression modelling was used to estimate normal stock performance through the period. The present study set the estimation period as 150 days 
before the event. The event dates for the three sample years of Super Bowl ads are shown in Table 2. The event periods were the Friday before $(t=-1)$, the Monday $(t=0$ : the event date), and Tuesday $(t=+1)$ through Friday $(t=+4)$. Because the stock markets are closed on Sunday, the event date is set as Monday. The numbers in parentheses indicate the number of days before $(-)$ or after $(+)$ the event date. Friday $(t=-1)$ before the Super Bowl was included in the event period because there has often been a considerable review of upcoming Super Bowl ads on Friday. The daily stock prices and market indices were obtained from the Wharton Research Data Services (WRDS) at the University of Pennsylvania. The data origin is the Center for Research in Security Prices (CRSP) at the University of Chicago. The market model that was used to estimate normal performance of stocks was estimated over the period using the following regression model:

$$
R_{j t}=\alpha_{j}+\beta_{j} R_{m t}+e_{j t}
$$

Where $R_{j t}$ is the observed daily return for company $j$ on day $t, \alpha_{j}$ is the intercept, $\beta_{j}$ is the regression coefficient for the company $j, R_{m t}$ is the observed daily return on the market index on day $t$, and $e_{j t}$ is the error term of the company $j$ on the trading day $t$. In the regression equation model, a company's stock return was the dependent variable and the daily return on the market index was the independent variable. Therefore, the model shows how a company's stock price has performed compared to the overall market conditions (ie return on the market index). The present study used the 'CRSP Value Weighted Return' as the return on market index in place of $R_{m t}$ because it reflected the performance of a weighted average portfolio of all stocks traded in the three major US stock exchanges (ie NYSE, AMEX and NASDAQ). The unexpected shareholder return, termed as 'abnormal returns' (AR) in event studies, at each day in the event period can be calculated as follows:

$$
A R_{j t}=R_{j t}-\left(a_{j}+b_{j} R_{m t}\right)
$$

Where $\left(a_{j}+b_{j} R_{m t}\right)$ is the predicted (or expected) stock return on day $t$ based on the company $j$ 's regression equation and $R_{j t}$ is the actual stock return of company $j$ on day $t$. Using this equation, the cumulative abnormal returns for the event period can be calculated by adding all the abnormal returns in the event period as follows:

$$
\operatorname{CAR}\left(T_{1}, T i\right)=\sum_{t=T_{l}}^{T_{i}} A R_{t}
$$

Finally, the statistical hypothesis tested in general event studies is: abnormal returns have occurred (Ha: $\mathrm{CAR} \neq 0$ ) or not $($ Ho: CAR $=0)$. Accordingly, this study's methodological hypothesis for the purpose of the event study can be stated as: 'Super Bowl advertising produced abnormal returns, on the days of the first week following the Super Bowl for the companies that advertised in the Super Bowl'.

\section{RESULTS}

Using the actual event period data and CRSP Value Weighted Return data, every expected return for the event period was calculated using the market models acquired from the regression analysis (Table 3). After testing the significance of the abnormal returns, differences in abnormal returns were studied by company types. The company types studied were 'dot.com' and 'bricks-and-mortar' companies. The rationale for using this dichotomous typology comes from the questions that 


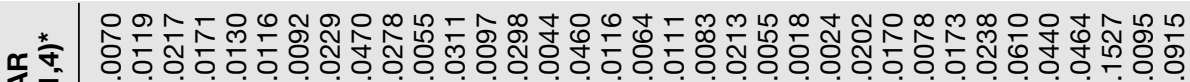
过吉

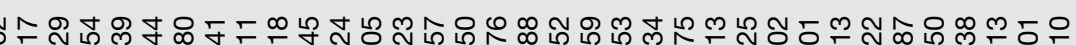

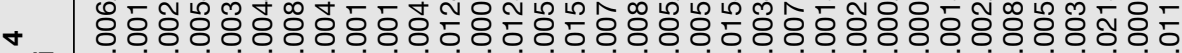

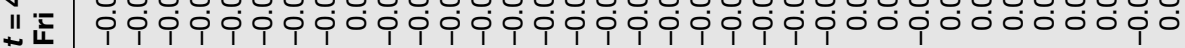

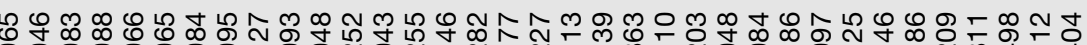

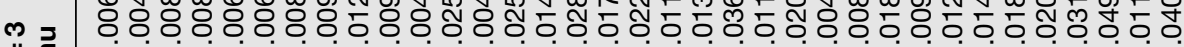
II

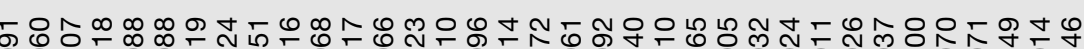

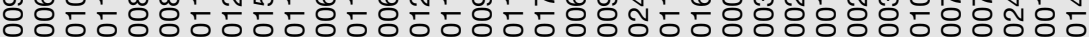

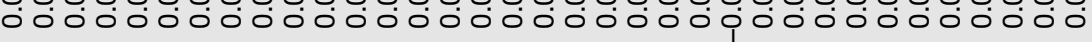

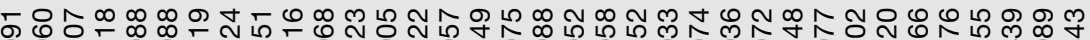

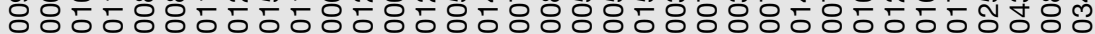

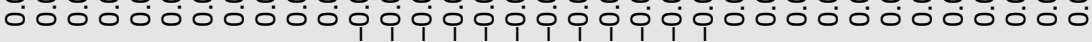

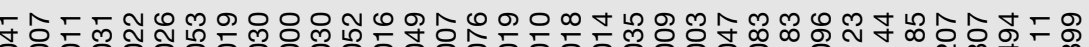

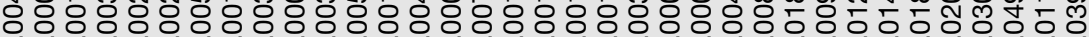

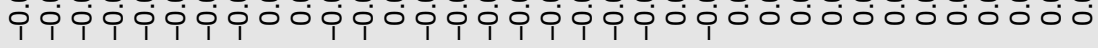

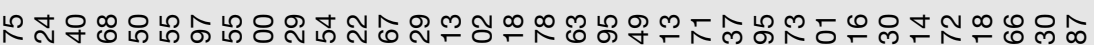

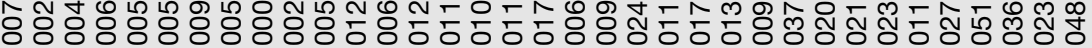

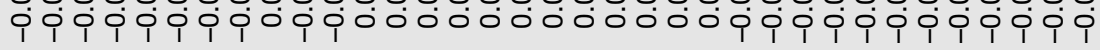

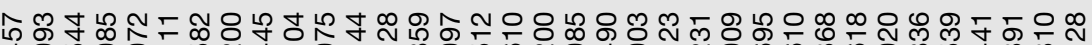

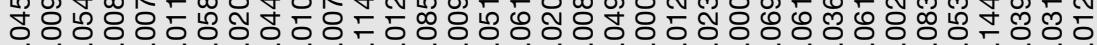

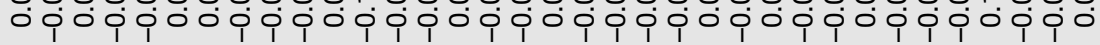

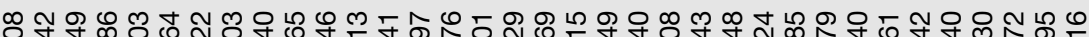

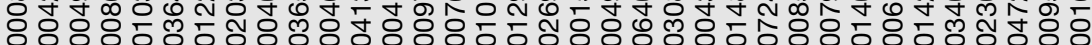

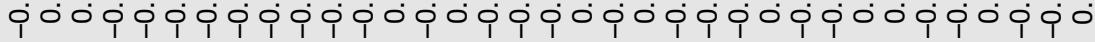

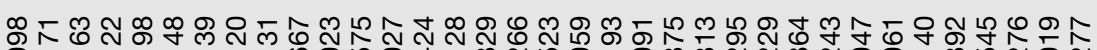

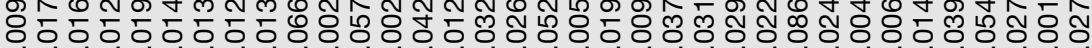
o o o

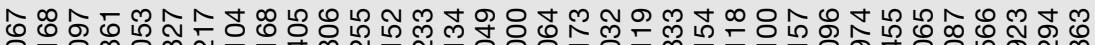

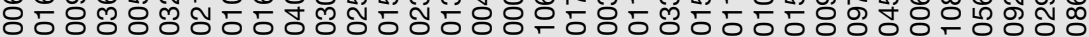
ípóno

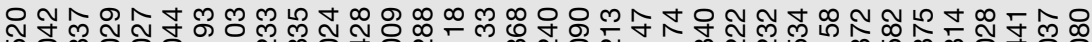

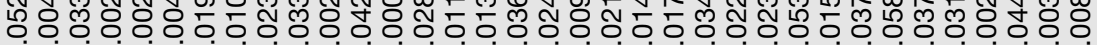

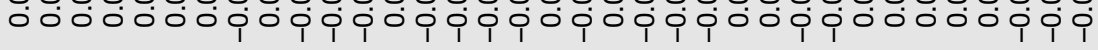

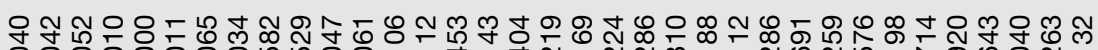

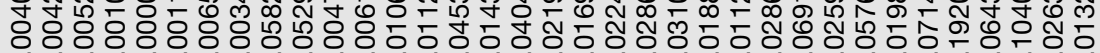
o

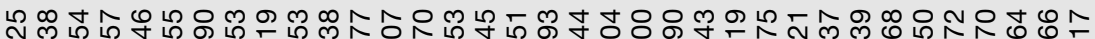

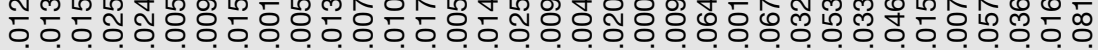

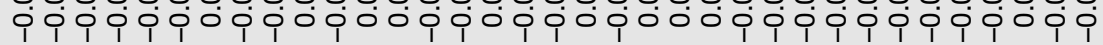

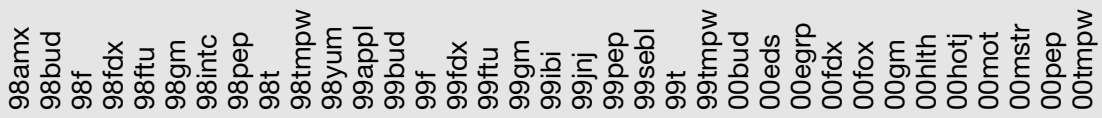


Table 4: ANOVA of same day comparisons between expected and actual returns

\begin{tabular}{|c|c|c|c|c|c|c|}
\hline & & Sum square & df & Mean & $\mathbf{F}$ & Sig. \\
\hline \multirow[t]{3}{*}{ Friday } & Between & 0.001 & 1 & 0.001 & 1.363 & 0.247 \\
\hline & Within & 0.038 & 68 & 0.001 & & \\
\hline & Total & 0.039 & 69 & & & \\
\hline \multirow[t]{3}{*}{ Monday } & Between & 0.006 & 1 & 0.006 & 5.150 & 0.026 \\
\hline & Within & 0.082 & 68 & 0.001 & & \\
\hline & Total & 0.088 & 69 & & & \\
\hline \multirow[t]{3}{*}{ Tuesday } & Between & 0.001 & 1 & 0.001 & 1.139 & 0.290 \\
\hline & Within & 0.032 & 68 & 0.000 & & \\
\hline & Total & 0.033 & 69 & & & \\
\hline \multirow[t]{3}{*}{ Wednesday } & Between & 0.002 & 1 & 0.002 & 1.971 & 0.165 \\
\hline & Within & 0.053 & 68 & 0.001 & & \\
\hline & Total & 0.055 & 69 & & & \\
\hline \multirow[t]{3}{*}{ Thursday } & Between & 0.000 & 1 & 0.000 & 0.079 & 0.779 \\
\hline & Within & 0.047 & 68 & 0.001 & & \\
\hline & Total & 0.047 & 69 & & & \\
\hline \multirow[t]{3}{*}{ Friday } & Between & 0.000 & 1 & 0.000 & 0.640 & 0.427 \\
\hline & Within & 0.022 & 68 & 0.000 & & \\
\hline & Total & 0.022 & 69 & & & \\
\hline
\end{tabular}

have arisen regarding the Super Bowl advertising effects for one type of company versus the other. ${ }^{51}$ More importantly, this dichotomy could serve as an operationalised typology for classifying a high FISA (dot.coms) and a low FISA (bricks-and-mortars). Because dot.com companies in the current research sample are small in size compared to bricks-and-mortars, and given the fact that their ad rates (ie ad expenses) were similar, the conceptual FISA proposed earlier indicates that dot.coms would have higher FISAs and the bricks-and-mortar companies would have lower FISAs. For instance, a high FISA suggests a high financial impact for the company airing the Super Bowl ads. Hypothesis 2 implies that a high FISA may lead to a negative stock price performance.

\section{Finding the abnormal returns}

An analysis of variance (ANOVA) was conducted to see whether cumulative abnormal returns existed. As Table 4 shows, a significant difference was found between expected and actual cumulative returns $(\mathrm{F}(1,68)=4.943, p=0.03$;
Levene Statistic $(1,68)=3.397$, $p=0.07)$, thus indicating the existence of abnormal returns. The mean of CAR (ie cumulative actual returns cumulative expected returns), -0.0232 (standard deviation $=0.057$ ), surprisingly shows that the overall abnormal returns were mostly negative. Among the companies, 22 showed negative and 13 showed positive abnormal returns. Companies that showed the most negative cumulative abnormal returns include MicroStrategy (0.1918 in 2000); Healtheon-WebMD (-0.1446 in 2000); and HotJobs.com (-0.0979 in 2000). Companies that made the most positive cumulative abnormal returns include Intel Corp. (0.049 in 1998); EDS (0.0493 in 2000); and Motorola (0.0978 in 2000).

Another ANOVA was conducted to see which particular days in the event window $(-1<t<4)$ showed significant abnormal returns. The result (Table 4) suggests that only Monday (ie event date) showed significant abnormal returns (mean difference $=-0.0188$, SE of difference $=0.0082, \mathrm{~F}(1,68)=5.15$, $p=0.026)$ among six days in the event window. These results imply that the effect of advertising on a company's stock 
Table 5: Monday $(t=0)$ 's descriptive statistics of AR by company types

\begin{tabular}{lrlll}
\hline & N & AR mean & Std. dev. & Std. error \\
\hline Bricks-and-mortar & 29 & -0.0049 & 0.03812 & 0.00708 \\
Dot.com & 6 & -0.0858 & 0.06753 & 0.02757 \\
\hline
\end{tabular}

price can be immediate, albeit short term. Since the Super Bowl ads are aired on one day only, these results are not surprising, and support the contention that advertising can influence the stock price of the advertiser. Based on these results, Hypotheses 1 and 2 were tested.

A correlation analysis was conducted to test $\mathrm{H}_{1}$, and to determine if there were significant relationships among abnormal returns (ie CARs), the likeability of advertising (ie Ad-Meter scores), and the frequency of advertising (ie number of spots). The result showed no significant correlation between CARs and the two advertising related variables (for CAR and Ad-Meter: $r=0.062$, $p>0.05$, CAR and number of spots: $r=0.144, p>0.05)$. These results showed that investors' reactions to the advertising were not dependent on the likeability of the advertising or frequencies of advertising. Thus $\mathrm{H}_{1}$ was not supported.

\section{Abnormal returns by company types: Testing $\mathrm{H}_{2}$}

In order to test $\mathrm{H}_{2}$, differences in abnormal returns by company type (ie dot.com and bricks-and-mortar), which operationally represent the two levels of FISA, were analysed using ANOVA. Among the 35 companies sampled, six were dot.coms. These include Monster.com (1998, 1999, and 2000), E-trade (2000), Web MD (2000) and HotJobs.com (2000). The results showed a significant difference for abnormal returns between two company types ( $\mathrm{F}$ $(1,33)=5.001, p<0.05 ;$ Levene Statistic
$(1,33)=0.019, p=0.891)$. The mean for the dot.com and the bricks-andmortar companies were $-0.0858(n=6$, Std. Dev. $=0.0675)$ and -0.0049 $(n=29$, Std. Dev. $=0.0381)$ respectively, showing the dot.com companies had significantly more negative abnormal returns than the more traditional bricks-and-mortar companies. As the analysis of within-the-same-day comparison (Table 4) showed, the abnormal returns between the dot.com and bricks-and-mortar companies on the Monday $(t=0)$ were significantly different between the two company types (see Tables 5 and 6). Although Thursday $(t=3)$ also showed a statistically significant difference, these results were discounted because the data from Thursday did not satisfy the homogeneity of variances assumption of an ANOVA (Levene Statistic $(1,33)=18.334$, $p<0.001)$. T-test under the non-equal-variances-assumption showed no significant difference between the company types $(t(5.329)=-1.65$, $p=0.156)$. Overall these results are considered sufficient support for Hypothesis $2\left(\mathrm{H}_{2}\right)$.

\section{DISCUSSION AND IMPLICATIONS}

This study showed that the Super Bowl advertisements had a significant, negative cumulative effect by appearing to create abnormal returns on stock prices of the advertising company, particularly on the Monday following the game. The findings suggest that Super Bowl advertising, from an equity position, could have been seen as an overly 
Table 6: ANOVA of same day comparison for two company types

\begin{tabular}{|c|c|c|c|c|c|c|}
\hline Event window & & $\begin{array}{l}\text { Sum of } \\
\text { squares }\end{array}$ & df & $\begin{array}{l}\text { Mean } \\
\text { square }\end{array}$ & $\mathbf{F}$ & Sig. \\
\hline \multirow[t]{3}{*}{ Friday $(t=1)$} & Between groups & 0.001 & 1 & 0.001 & 2.583 & 0.118 \\
\hline & Within groups & 0.018 & 33 & 0.001 & & \\
\hline & Total & 0.019 & 34 & & & \\
\hline \multirow{3}{*}{ Monday $(t=0)$} & Between groups & 0.032 & 1 & 0.032 & 16.886 & 0.000 \\
\hline & Within groups & 0.063 & 33 & 0.002 & & \\
\hline & Total & 0.096 & 34 & & & \\
\hline \multirow{3}{*}{ Tuesday $(t=1)$} & Between groups & 0.003 & 1 & 0.003 & 3.341 & 0.077 \\
\hline & Within groups & 0.026 & 33 & 0.001 & & \\
\hline & Total & 0.029 & 34 & & & \\
\hline \multirow[t]{3}{*}{ Wednesday $(t=2)$} & Between groups & 0.002 & 1 & 0.002 & 1.722 & 0.198 \\
\hline & Within groups & 0.047 & 33 & 0.001 & & \\
\hline & Total & 0.050 & 34 & & & \\
\hline \multirow[t]{3}{*}{ Thursday $(t=3)$} & Between groups & 0.004 & 1 & 0.004 & 8.184 & 0.007 \\
\hline & Within groups & 0.016 & 33 & 0.000 & & \\
\hline & Total & 0.020 & 34 & & & \\
\hline \multirow[t]{3}{*}{ Friday $(t=4)$} & Between groups & 0.002 & 1 & 0.002 & 2.515 & 0.122 \\
\hline & Within groups & 0.022 & 33 & 0.001 & & \\
\hline & Total & 0.023 & 34 & & & \\
\hline
\end{tabular}

expensive rather than an efficient investment. In addition, these results seem to support Ely and Waymire's ${ }^{52}$ view that investors do not view advertising as a predictor of better company performance. In fact, in some cases it may be seen from the opposite perspective. Ely and Waymire ${ }^{53}$ stated that investors value companies primarily based on earnings, and would not appear to see advertisements as directly engendering better company performances in the near future.

As the significant difference in abnormal returns between dot.coms and bricks-and-mortars seemed to show, many financial analysts believe that Super Bowl advertising would bring about a very poor return on investment, especially for many of the dot.coms. For example, internet traffic data showed that more than two-thirds of the dot.com companies that advertised in the Super Bowl noticed a large drop in traffic a week after the Super Bowl. ${ }^{54}$ Investors might fear these future consequences and, therefore, react immediately after witnessing this costly advertising. The immediacy of the investor reaction was verified through the results that showed significant abnormal returns and the significant differences in abnormal returns between online and offline companies, immediately following (the Monday after) the Super Bowl advertising.

The major goal of most corporate communication efforts is to build favourable consumer perceptions and attitudes towards their brands. In most cases, advertising has been one of the most utilised communications tools for achieving that goal. Consumers are not the only target audience of that communications effort, however. There are many important peripheral groups that are affected by these communications, which can in turn influence the success of a company. Among them, as this study showed, are the investors who may not react as expected to corporate communication activities, particularly if these activities are known to be expensive.

Moreover, this study found no relationship between stock price performances and ad likeability or ad frequency. The implication is that investors may focus less on the content 
of ads than on the fact that companies, particularly those with short track records, are making large expenditures. They may, therefore, question the decision making at the corporate level.

While most companies in this study showed significant negative abnormal returns during the testing period, a few companies actually showed significant positive abnormal returns (for example, Intel Corp. in 1998 showed a positive cumulative abnormal return of 0.049). This may indicate that either certain types of advertising strategies have a positive effect on stock prices, or more likely that certain stocks are unaffected by the phenomenon due to the nature of the business.

Advertising efficiency among consumer audiences has always been a concern, but the results of the present study imply that companies may need to consider and address investor exposure when designing marketing communications plans.

Investors are a major stakeholder group, and as part of the integrated communications process, public relations could be important in addressing these concerns. In addition to the traditional post-advertising research, companies need to analyse the stock price reactions to their communication activities, especially when these activities are salient and in high profile environments, such as the Super Bowl.

The purpose of this study was to explore how investors or equity stockholders perceive advertising. The result, however, should be interpreted in light of Super Bowl advertising only. This may be unique when compared to other forms of marketing. In addition, the non-significant relationship between stock price performances and the likeability of ads should be examined, especially in view of the limitations of the Ad-Meter's validity. Future studies, with larger samples, additional variables such as PE ratio, stock trading volume and some psychological variables, should be used to investigate the reasons behind abnormal returns following an advertising event, by providing insights into the effects of a company's advertising on the thoughts, feelings and intentions of stock traders who view them.

\section{References}

1 DeGraw, I. (2000) 'A news-based investment strategy', in Crosswalk.com Money Channel. Reprinted with permission from World Finance Net IPO Newsletter 2000.

2 White, J. B. and Miles, M. P. (1996) 'The financial implications of advertising as an investment', Journal of Advertising Research, Vol. 36, No. 4, pp. 43-52.

3 Chauvin, K. W. and Hirchey, M. (1993) 'Advertising, R\&D expenditures and the market value of the firm', Financial Management, Vol. 22, No. 4, pp. 128-140.

4 Mathur, L. K. and Mathur, I. (1995) 'The effect of advertising slogan changes on the market value of firms', Journal of Advertising Research, Vol. 35, No. 1, pp. 59-65.

5 Demsetz, H. (1973) 'Industry structure, market rivalry and public policy', Journal of Law and Economics, Vol. 16, No. 1, pp. 1-11.

6 Ayanian, R. (1983) 'The advertising capital controversy', Journal of Business, Vol. 56, No. 3, pp. 349-364.

7 Schultz, D. E. (1990) 'Strategic advertising campaigns', NTC Business Books; Lincolnwood, IL.

8 Jones, J. P. (1995) 'When ads work', Lexington Books, New York, NY.

9 Pitelis, C. N. (1991) 'The effects of advertising and investment in aggregate profits', Scottish Journal of Political Economy, Vol. 38, No. 1, pp. 32-40.

10 Simon, J. L. and Arndt, J. (1980) 'The shape of the advertising response function', Journal of Advertising Research, Vol. 20, No. 4, pp. 11-28.

11 Marquardt, R. A. and Murdock, G. W. (1984) 'The sales/advertising relationship: An investigation of correlations and consistency in supermarkets and department stores', Journal of Advertising Research, Vol. 24, No. 5, pp. 55-60.

12 Nerlove, M. and Kenneth, J. (1962) 'Optimal advertising policy under dynamic conditions', Economica, 29th May, pp. 129-142.

13 Farris, P. W. and Buzzell, R. D. (1979) 'Variations in advertising intensity: Some cross-sectional analysis', Journal of Marketing, Vol. 43, No. 4, pp. 112-122.

14 Farris, P. W. and Albion, M. S. (1981) 'Determinants of the advertising to sales ratio', Journal of Advertising Research, Vol. 21, No. 1, pp. 19-27.

15 Ailawadi, K. L., Farris, P. W. and Parry, M. E. (1994) 'Share and growth are not good predictors of the advertising and promotion/sales ratio', Journal of 
Marketing, Vol. 58, No. 1, pp. 86-97.

16 Dhalla, N. K. (1976) 'Assessing the long-term value of advertising', Harvard Business Review, Vol. 54, No. 1, pp. 87-95.

17 Tanenbaum, J. (1993) 'AcSEC Update: Financial accounting', Journal of Accountancy, Vol. 175, No. 6, pp. $79-80$.

18 White and Miles (1996) op. cit.

19 Jones (1995) op. cit.

20 Broadbent, S. (1993) 'Advertising effects: More than short term', Journal of the Market Research Society, Vol. 35, No. 1. pp. 37-49.

21 Ibid.

22 Case, K. E. and Shamblin, J. E. (1972) 'The effects of advertising carry-over', Journal of Advertising Research, Vol. 12, No. 3, pp. 37-40.

23 Clarke, D. G. (1976) 'Econometric measurement of the duration of advertising effect of sales', Journal of Marketing Research, Vol. 13, No. 4, pp. 345-357.

24 Jones (1995) op. cit.

25 Kotler, P. (1994) 'Marketing management: analysis, planning, implementing, and control', Prentice-Hall, Inc., Englewood Cliffs, NJ.

26 Chauvin and Hirchey (1993) op. cit.

27 Mathur and Mathur (1995) op. cit.

28 Barth, M., Clement, M., Foster, G. and Kasznik, R. (1998) 'Brand values and capital market valuations', Review of Accounting Studies, Vol. 3, 3rd June, pp. 41-68.

29 Chauvin and Hirchey (1993) op. cit.

30 Mathur and Mathur (1995) op. cit.

31 Barth et al. (1998) op. cit.

32 Ely, K. and Waymire, G. (1998) 'Intangible assets and stock prices in the pre-SEC era', Journal of Accounting Research, Vol. 37, No. 3, pp. 17-44.

33 Duncan, T. and Moriarty, S. (1997) 'Driving brand value: using integrated marketing to manage profitable stakeholder relationships', McGraw-Hill, New York.

34 Binder, J. J. (1998) 'The event study methodology since 1969', Review of Quantitative Finance and Accounting, Vol. 11, No. 2, pp. 111-137.

35 Stayman (1999) 'Are Super Bowl ads worth the expense?', Cornell University Press Release.

36 Goldberg, M., Bergstein, A. and Chang, J. (2001) 'Advertising during the Super Bowl can be prime-time blunder', Article from Penn State University Smeal College of Business Administration. 37 Binder (1998) op. cit.

38 Mitchell, M. (1989) 'The impact of external parties on brand-name capital: the 1982 Tylenol poisonings and subsequent cases', Quarterly Journal of Economics, Vol. 25, No. 4, pp. 601-618.
39 Aharony, J. and Swary, I. (1996) 'Additional evidence on the information-based contagion effects of bank failures', Journal of Banking and Finance, Vol. 20, No. 1, pp. 57-69.

40 Ormanidou, E. and Thomsen, M. (2000) 'Stock market reactions to unfavorable product information: A case study of comments on beef safety made on an Oprah Winfrey show', The Student Journal of The Dale Bumpers College of Agricultural, Food and Life Sciences, Vol. 1, No. 1, pp. 3-9.

41 Bartov, E. Lindahl, F. W. and Ricks, W. E. (1998) 'Stock price behavior around announcements of write-offs', Review of Accounting Studies, Vol. 3, No. 4, pp. 327-346.

42 Prather, L. J. and Min, J. H. (1998) 'Testing of the positive-multinational network hypothesis: wealth effects of international joint ventures in emerging markets', Multinational Finance Journal, Vol. 2, No. 2, pp. 151-165.

43 Park, C. W. and Stice, E. K. (2000) 'Forecasting ability and the stock price reaction to forecast revisions, Review of Accounting Studies, Vol. 5, No. 3, pp. 259-272.

44 Soffer, L. C., Thiagarajan, S. R. and Walther, B. R. (2000) 'Earnings preannouncement strategies', Review of Accounting Studies, Vol. 5, No. 1, pp. $5-26$.

45 Mathur, L. K., Mathur, I. and Rangan, N. (1997) 'The wealth effects associated with a celebrity endorser: the Michael Jordan phenomenon', Journal of Advertising Research, Vol. 37, No. 3, pp. 67-73.

46 Lane, V. and Jacobson, R. (1995) 'Stock market reactions to brand extension announcements: The effects of brand attitude and familiarity', Journal of Marketing, Vol. 59, January, pp. 63-77.

47 Bowman, R. G. (1983) 'Understanding and conducting event studies', Journal of Business, Finance and Accounting, Vol. 10, No. 4, pp. 561-584.

48 Brown, S. J. and Warner, J. B. (1980) 'Measuring security price performance', Journal of Financial Economics, Vol. 8, No. 3, pp. 205-258.

49 Schwert, G. W. (1981) 'Using financial data to measure effects of regulation', Journal of Law and Economics, Vol. 24, No, 1, pp. 121-158.

50 Strong, N. (1992) 'Modeling abnormal returns: A review article', Journal of Business Finance and Accounting, Vol. 19, No. 4, pp. 533-553.

51 USA Today (2001) 'USA Today Super Bowl XXXV Ad-Meter'.

52 Ely and Waymire (1993) op. cit.

53 Ibid.

54 CNETNews.com. (2000) 'Sites spend billions on ads, but will they get their money back?, 21st February. 